\title{
PEGARUH HARGA DAN KUALITAS PRODUK TERHADAP KEPUTUSAN PETANI MEMBELI BIBIT SAWIT DI PT. BIO NUSANTARA TEKNOLOGI BENGKULU
}

\author{
Nurzam, Rani Sari Fauziah, dan Karona Cahya Susena \\ Program Studi Manajemen, Fakultas Ekonomi, Universitas Dehasen Bengkulu \\ karona.cs@unived.ac.id
}

\begin{abstract}
ABSTRAK
Nurzam, Rani Sari Fauziah, dan Karona Cahya Susena; Penelitan ini bertujuan untuk mengetahui pengaruh harga dan kualitas bibit terhadap keputusan petani membeli bibit sawit di PT. Bio Nusantara Teknologi Bengkulu. Jenis penelitan ini adalah deskriptif dengan pendekatan kuantiatif. Jenis data yang digunakan adalah data primer yang diperoleh melalui penyebaran kuesioner dan observasi. Responden dalam penelitan adalah petani yang membeli bibit sawit pada PT. Bio Nusantara Teknologi Bengkulu yang berjumlah 50 orang. Sampel penelitan diambil dengan teknik acidental sampling. Metode analisis data digunakan analisis regresi berganda. Dari hasil penelitan diperoleh diketahui bahwa: (1) Harga berpengaruh positf dan signifikan terhadap keputusan petani membeli bibit kelapa sawit di PT. Bio Nusantara Teknologi Bengkulu. Hasil ini bermakna bahwa jika bibit

dipersepsikan terjangkau, maka keputusan petani membeli bibit akan semakin tingi; (2) Kualitas bibit berpengaruh positf dan signifikan terhadap keputusan petani membeli bibit kelapa sawit di PT. Bio Nusantara Teknologi Bengkulu. Hasil ini bermakna bahwa jika kualitas bibit dipersepsikan semakin tingi, maka keputusan petani membeli bibit akan semakin tingi; dan (3) Harga dan kualitas bibit berpengaruh positf dan signifikan terhadap keputusan petani membeli bibit kelapa sawit di PT. Bio Nusantara Teknologi Bengkulu. Hasil ini bermakna bahwa jika bibit dipersepsikan terjangkau dan kualitas bibit semakin baik, maka keputusan petani membeli bibit akan semakin tinggi.
\end{abstract}

\section{ABSTRACT}

Nurzam, Rani Sari Fauziah, dan Karona Cahya Susena; This research aims to determine the influence of price and quality of seedlings against farmers ' decision to buy palm seed in PT. Bio Nusantara Teknologi Bengkulu. This type of research is descriptive with a quantiative approach. The type of data used is primary data obtained through the dissemination of questionnaires and observations. Respondents in the research were farmers who bought oil palm seedlings at PT. Bio Nusantara Teknologi Bengkulu amounting to 50 people. Sample of the research is taken with acidental sampling technique. Data analysis methods used multiple regression analyses. From the results of the research acquired that: (1) The price has a positive effect and significant to the decision of farmers to buy oil palm seedlings in PT. Bio Nusantara Teknologi Bengkulu. This result means that if the seedling

Affordable, then farmers ' decision to buy seedlings will be increasingly tingi; (2) The seed quality is positive and significant to the decision of farmers buying oil palm seedlings in PT. Bio Nusantara Teknologi Bengkulu. This result means that if the seed quality is being perceived to be more high, then the decision of farmers to buy seedlings will be more high; and (3) prices and quality of seedlings influence POSITF and significant to the decision of farmers buy oil palm seedlings in PT. Bio Nusantara Teknologi Bengkulu. This result means that if the seeds are perceived to be affordable and seed quality is getting better, then the decision offarmers buying seeds will be higher.

Keywords: price, product quality, decision

\section{LATAR BELAKANG}

Luas Kabupaten Bengkulu Tengah 554.854 Ha, terdiri dari 253.457 Ha areal hutan, 202.329 Ha areal budi daya dan 99.068 Ha merupakan areal perkampungan. Dari luas areal budi daya 202.329 Ha tersebut, yang berpotensi pada subsektor perkebunan 170.968 Ha $(84,5 \%)$ dan yang telah diusahakan hingga saat ini seluas 107.623,05 Ha terdiri dari 30.701,05 Ha yang diusahakan oleh Perkebunan Besar Swasta (PBS) dengan jenis komoditi yang diusahakan adalah kelapa sawit, karet, dan kakao. Sementara perkebunan rakyat seluas 76.922 Ha dengan jenis komoditi yang beragam dan yang belum digarap berupa lahan tidur (land sleeping) seluas 63.344,95 Ha. Jumlah penduduk pada sensus tahun 2018 sebanyak 120.211 jiwa dengan jumlah kepala keluarga (KK) sebanyak 27.815. Mata pencarian sebagian besar penduduk di sektor pertanian/ perkebunan, selebihnya di sektor industri kecil, perdagangan dan jasa (BPS Bengkulu Utara, 2018). 
Pembangunan pertanian dan perkebunan mempunyai tujuan akhir meningkatkan kesejahteraan petani dan keluarganya serta masyarakat pada umumnya. Untuk itu, ditempuh berbagai kebijaksanaan yang dijabarkan melalui tahapan pembangunan nasional. Pembangunan pertanian diarahkan pada peningkatan sumberdaya manusia dan masyarakat yang maju dan mandiri, dalam arti memberikan kondisi dan peluang guna menumbuhkan prakarsa serta kreativitas dalam pembangunan baik subjek maupun melakukan fungsi pengawasan. Ada beberapa faktor yang mempengaruhi keberhasilan usaha pertanian adalah sapta usaha tani yakni: pengolahan tanah, benih unggul, pemupukan, pengendalian hama dan penyakit, pengairan, pengolahan hasil dan pemasaran (Fahmi dan Bilkis, 2017:12). Selain itu, keberhasilan pertanian juga dipengaruhi oleh bibit, lahan dan manajemen. Sebagai salah satu penunjang keberhasilan usaha, manajemen harus mendapat perhatian yang sama dengan faktor lain. Keberhasilan manajemen sangat dipengaruhi oleh kualitas sumber daya manusia (Sukirno, 2012:123).

Manajemen usaha tani adalah penggunaan secara efektif sumber-sumber yang terdapat dalam usaha tani. Manajemen usaha tani juga diartikan sebagai pengaturan dan penyelenggaraan pertanian secara memadai dengan menggunakan tiga aspek, yakni input, proses dan output. Input merupakan sumber masukan dari usaha tani yang dilakukan yang terdiri dari bahan baku, tenaga, luas lahan, bahan penunjang dan sebagainya. Dimensi proses merupakan kegiatan dalam pengelolaan yang melibatkan manusia, teknik pertanian dan sebagainya. Dimensi output merupakan keluaran usaha tani seperti kualitas produksi, kuantitas hasil dan sebagainya (Rangkuti, 2003:54).

Sebagaimana telah disinggung sebelumnya, faktor kualitas produk atau kualitas bibit menjadi faktor penting dalam mempengaruhi keputusan petani dalam membeli bibit tersebut, selain harga yang terjangkau. Hal ini karena bibit tanaman khususnya bibit yang ditanam merupakan investasi jangka panjang, sehingga harus dipilih bibit-bibit yang memiliki kualitas dan produktivitas yang tinggi. Jaminan kualitas yang diberikan terhadap bibit adalah adanya sertifikasi bibit sawit dari instansi yang berwenang (Dinas Pertanian, 2018:88).

Selanjutnya, faktor harga juga dapat mempengaruhi keputusan konsumen dalam membeli produk. Dalam hal ini harga bibit juga dapat mempengaruhi petani kelapa sawit untuk membeli bibit sawit. Bibit sawit yang berkualitas tentu saja akan memiliki tingkat harga yang relatif lebih tinggi dibandingkan dengan bibit-bibit yang tidak bersertifikat. Oleh karena itu, petani kelapa sawit akan mempertimbangkan faktor harga dan kualitas bibit sebelum melakukan keputusan untuk membeli bibit tersebut.

Berkenaan dengan penyediaan bibit, PT. Bio Nusantara Teknologi merupakan perusahaan yang bergerak di bidang pertanian dan perkebunan kelapa sawit yang besar di Bengkulu. Selain memiliki usaha perkebunan kelapa sawit, PT Bio Nusantara Teknologi juga mengembangkan usaha pembibitan kelapa sawit dengan skala besar. Rata-rata bibit-bibit sawit yang dikembangkan di perusahaan ini dijual di daerah Bengkulu sendiri dan daerah lain seperti Kabupten Musi Rawas, Lubuklinggau, Kabupaten Sarolangun Jambi dan sebagainya. Bibit-bibit kelapa sawit tersebut telah menempuh proses sertifikasi yang cukup panjang, sehingga memberikan jaminan kualitas kepada petani yang membeli bibit.

Berdasarkan hasil survey awal di lokasi pembibitan PT. Bio Nusantara Teknologi Bengkulu menyediakan bibit kelapa sawit yang berasal dari Provinsi Sumatera Utara. Tiga kelompok bibit sawit yang ada di area pembibitan kelapa sawiat PT. Bio Nusantara Teknologi adalah sebagai berikut:

Tabel 1. Jenis Bibit Kelapa Sawit di PT. Bio Nusantara Teknologi

\begin{tabular}{|c|c|c|c|}
\hline No & Jenis & Varietas & Keterangan \\
\hline 1 & PPKS & $\begin{array}{ll}- & \text { DxP Simalungn } \\
- & \text { DxP Dumpy } \\
- & \text { DxP 540 } \\
- & \text { DxP 239 } \\
- & \text { DxP 718 } \\
\end{array}$ & Dijual umum \\
\hline 2 & Socfin & $\begin{array}{ll}\text { - } & \text { Yangambi } \\
\text { - } & \text { Lame } \\
\end{array}$ & Dijual umum \\
\hline 3 & Lonsum & Bahlias & Dibudidayakan di kebun perusahaan \\
\hline
\end{tabular}

Sumber: PT. Bio Nusantara Teknologi Bengkulu, 2019

Bibit-bibit kelapa sawit tersebut merupakan bibit dengan sertifikasi resmi. Bibit tersebut dijual dengan melihat umur bibit, mulai dari harga Rp. 42.000,00 sampai dengan Rp. 47.000,00. Harga-harga tersebut ditetapkan untuk jenis bibit PPKS dan Socfin yang kecambahnya berasal dari Pusat Penelitian Kelapa Sawit Medan Sumatera Utara dan Socfin Indonesia. Pengambilan bibit di daerah Medan Sumatera Utara tersebut dikarenakan pusat pembibitan kelapa sawit di Indonesia berasal dari Medan tersebut. Standar-standar bibit yang dari PPKS (Pusat Penelitian Kelapa Sawit) Medan dan Socfin Medan adalah sebagai berikut: 
Tabel 2. Hasil Pemeriksaan Benih

\begin{tabular}{|l|l|l|}
\hline Parameter & Standar (ISO: 9001:2008) & Hasil Pemeriksaan Bibit \\
\hline Umur (bulan) & $>12$ & 12 \\
Jumlah Pelepah Daun & $\geq 15$ & $14-21$ \\
Warna Daun & Hijau Tua & Hijau Tua \\
Kemasaran Polybag Hitam (cm) & $30-40 \times 40-50$ & $40 x 50$ \\
Kesehatan & Bebas hama dan penyakit utama & Bebas hama dan penyakit utama \\
\hline
\end{tabular}

Sumber: PT. Bio Nusantara Teknologi Bengkulu, 2019

Walaupun harga tersebut tergolong tinggi dibandingkan dengan bibit yang dijual oleh pesaing, seperti pembibitan UPK Harapan Tani yang beralamat di Bengkulu Utara dengan harga Rp37.000,00, Koperasi Aldece Makarti Muktitama yang beralamat di Bengkulu Utara dengan harga Rp36.000,00, UPK Yahyo yang beralamat di Seluma dengan harga Rp38.000,00 dan UD. Nasari Sarana Perkasa yang beralamat di Kota Bengkulu dengan harga Rp38.000,00, namun masyarakat petani tetap memilih bibit dari PT. Bio Nusantara Teknologi. Hal ini dikarenakan usaha-usaha pembibitan yang dilakukan oleh para pesaing, murni usaha pembibitan (tidak memiliki kebun produksi), sementara PT. Bio Nusantara Teknologi dipercaya karena memiliki kebun produksi yang dapat dilihat langsung (sampel yang sudah berbuah) oleh para konsumen saat ingin membeli bibit. Selain itu, konsumen juga memberikan jaminan kualitas bibit dengan adanya sertifikasi bibit yang dikeluarkan oleh instansi berwenang, baik dari produsen bibit langsung (dari Medan) maupun dari pemerintah daerah Provinsi Bengkulu. Sertifikasi bibit tersebut telah mendorong dan menguatkan masyarakat petani untuk membeli bibit di PT. Bio Nusantara Teknologi.

Selain, keunggulan tersebut, kelebihan-kelebihan yang diberikan oleh PT. Bio Nusantara Teknologi adalah masyarakat petani mendapatkan pembinaan langsung dari perusahaan bagi petani yang menginginkannya, contoh sampel yang sudah produksi dapat dilihat langsung di kebun produksi dengan melihat label yang ada pada batang, petani mendapat pengetahuan cara menanam yang baik dan benar secara gratis dari perusahaan baik dari kegiatan pameran dan lokakarya yang diselenggarakan perusahaan.

Tujuan yang akan di capai dalam penelitian ini adalah untuk: (1) Mengetahui pengaruh harga terhadap keputusan konsumen membeli Bibit kelapa sawit di PT. Bio Nusantara Teknologi Bengkulu. (2) Mengetahui pengaruh kualitas produk terhadap keputusan konsumen membeli Bibit kelapa sawit di PT. Bio Nusantara Teknologi Bengkulu. (3) Mengetahui pengaruh harga dan kualitas produk terhadap keputusan konsumen membeli Bibit kelapa sawit di PT. Bio Nusantara Teknologi Bengkulu.

Manfaat penelitian ini dapat berguna bagi beberapa pihak, antara lain sebagai berikut: (1) Bagi pihak perusahaan, hasil penelitian dapat digunakan sebagai masukan untuk mengetahui pengaruh harga dan kualitas produk terhadap keputusan konsumen, sehingga dapat dijadikan bahan evaluasi dalam strategi pemasaran produk. (2) Diharapkan dapat memberikan masukan untuk pengembangan keilmuan/ wawasan/pengetahuan khususnya dalam bidang manajemen pemasaran. (3) Bagi Penulis adalah untuk memperluas wawasan, menambah khasanah ilmu pengetahuan dan memberikan kontribusi temuan ilmiah terhadap ilmu manajemen pemasaran, dan menunjang pekerjaan penulis dalam bidang pemasaran.

Penelitian ini dilakukan di Kota Bengkulu, kajian penelitian ini dibatasi dengan fokus kepada pengaruh harga dan kualitas produk terhadap keputusan pembelian konsumen. Konsumen yang diteliti adalah petani yang membeli bibit kelapa sawit di PT. Bio Nusantara Teknologi Bengkulu.

\section{METODE PENELITIAN}

Jenis penelitian ini dilakukan dengan menggunakan metode deskriptif kuantitatif. Menurut Sugiyono (2010:76) penelitian deskriptif kuantitatif adalah yang berusaha menggambarkan dan menjelaskan suatu fenomena tertentu yang terjadi di lapangan melalui perhitungan angka-angka statistik. Penelitian ini berusaha mengetahui pengaruh harga dan kualitas produk (bibit) terhadap keputusan konsumen membeli Bibit kelapa sawit di PT. Bio Nusantara Teknologi Bengkulu.

Menurut Sugiyono (2010:234) populasi adalah wilayah generalisasi yang terdiri atas objek atau subjek yang mempunyai kualitas dan karakteristik tertentu yang ditetapkan oleh peneliti untuk dipelajari dan kemudian ditarik kesimpulannya. Populasi dalam penelitian ini adalah seluruh konsumen (petani) yang membeli Bibit kelapa sawit di PT. Bio Nusantara Teknologi Bengkulu.

Menurut Sugiyono (2010:234) sampel adalah sebagian objek atau subjek yang mempunyai kualitas dan karakteristik tertentu yang ditetapkan oleh peneliti untuk dipelajari dan kemudian ditarik kesimpulannya. Sampel dalam penelitian ini adalah sebagian konsumen yang membeli Bibit kelapa sawit di PT. Bio Nusantara Teknologi Bengkulu. Metode yang digunakan dalam penelitian ini adalah accidental sampling. Jumlah sampel yang akan diambil adalah sebanyak 50 orang. Menurut pendapat Sugiyono 
(2010:43) jumlah sampel untuk analisis multivariate sebaiknya harus lebih besar dari 30 (n>30). Hal tersebut sejalan dengan teori cental limit, bahwa jika jumlah sampel lebih besar $30(n>30)$, maka data dapat digeneralisasi (Ghozali, 2013:124). Jadi, jumlah sampel sebanyak 50 orang lebih besar dari 30. Teknik pengumpulan data yang dilakukan dengan cara memberi seperangkat pertanyaan atau pernyataan tertulis kepada responden untuk dijawab. Kuesioner yang disebarkan kepada responden merupakan kuesioner tertutup, yakni kuesioner yang berisi pertanyaan-pertanyaan penelitian berikut dengan pilihan jawaban. Penyebaran kuesioner langsung dibagikan kepada konsumen yang membeli Bibit kelapa sawit di PT. Bio Nusantara Teknologi Bengkulu yang terpilih menjadi responden penelitian.

\section{Pengujian Validitas}

Uji validitas digunakan untuk mengukur sah atau valid tidaknya suatu kuesioner (Sugiyono, 2010:123). Pengukuran validitas dilakukan dengan menghitung korelasi (r-hitung) antara skor item dengan skor total suatu variabel. Nilai r-hitung dengan diperoleh teknik Pearson Correlation. Kriteria pengujiannya adalah :

- Jika r-hitung < r-tabel pada kesalahan 5\% $(0,05)$ maka item tidak valid

- $\quad$ Jika r-hitung > r-tabel pada kesalahan 5\% $(0,05)$ maka item valid

Item-item yang valid dinilai tepat digunakan sebagai instrumen penelitian, sedangkan item-item yang tidak valid, berarti item tersebut tidak tepat (tidak sah) digunakan sebagai instrumen penelitian (Sugiyono, 2010:125).

\section{Pengujian Reliabilitas}

Uji reliabilitas dimaksudkan untuk mengukur tingkat kehandalan suatu instrumen penelitian. Suatu kuesioner dikatakan reliabel atau handal jika jawaban seseorang terhadap pertanyaan adalah konsisten atau stabil dari waktu ke waktu (Sugiyono, 2010:127). Uji reliabilitas diukur dengan uji statistik Cronbach's Alpha (a), yaitu suatu variabel dikatakan reliable jika memberikan nilai Cronbach's Alpha $>0,60$ (Sugiyono, 2010:127). 2010:127):

Kriteria dalam menguji reliabilitas instrumen penelitian adalah sebagai berikut (Sugiyono,

a. Nilai Cronbach'sAlpha $\geq 0,60$, artinya data bersifat reliable (dapat dipercaya).

b. Nilai Cronbach'sAlpha $<0,60$, artinya data tidak reliable (tidak dapat dipercaya).

\section{Uji Asumsi Klasik}

Uji asumsi klasin dipergunakan untuk mengetahui bahwa data penelitian memiliko kondisi BLUE (Best Linear Unbias Estimate) sehingga hasilnya dapat digeneralisir (Ghozali, 2011). Uji asumsi klasik yang dilakukan terdiri dari uji normalitas, uji multikolenieritas dan uji heterosekedastisitas.

\section{Uji Normalitas}

Uji normalitas bertujuan untuk menguji apakah dalam model regresi, variabel pengganggu atau residual memiliki distribusi normal.Seperti diketahui bahwa uji $\mathrm{t}$ dan $\mathrm{F}$ mengasumsikan bahwanilai residual mengikuti distribusi normal.Kalau asumsi ini dilanggarmaka uji ststistik menjadi tidak valid untuk jumlah sampel yang kecil (Ghozali, 2011).

\section{Uji Multikolonieritas}

Uji mutikolonieritas bertujuan untuk menguji apakah model regresi ditemukan adanya korelasi antar variabel bebas (independen). Model regresi yang baik seharusnya tidak terjadi korelasi di antara variabel independen. Menurut Ghozali (2011) dijelaksan untuk mendeteksi ada atau tidaknya multikolonieritas didalam mode regresi adalah sebagai berikut:

1. Nilai tolerance dan lawannya

2. Variance Inflation Factor (VIF).

Kedua ukuran ini menunjukkansetiap variabel independen manakan yang dijelaskan oleh variabel independen lainnya.

\section{Uji Heteroskedastisitas}

Uji heteroskedastisitas bertujuan menguji apakah dalam model regresi terjadi ketidaksamaan variance dari residual satu pengamatan ke pengamatan yang lain. Jika varian dari residual satu pengamatan ke pengamatan lain tetap, maka disebut hommoskedastisitas dan jika berbeda disebut heteroskedastisitas. Model regresi yang baik yaitu homoskedastisitas (Ghozali, 2011). 
Analisis Regresi Linier Berganda

Analisis regresi berganda dalam penelitian ini digunakan untuk mengetahui pengaruh variabel independent terhadap variabel dependent. Variabel independent dalam penelitian ini adalah harga dan kualitas produk. Sedangkan variabel dependent-nya adalah keputuan pembelian konsumen. Persamaan regresi yang digunakan adalah sebagai berikut:

$$
\mathrm{Y}=\alpha+\mathrm{b}_{1} \mathrm{X}_{1}+\mathrm{b}_{2} \mathrm{X}_{2}+\varepsilon
$$

\section{Koefisien Korelasi Berganda}

Analisis korelasi berganda digunakan untuk mengukur keeratan hubungan antaraharga dan kualitas produk secara bersama-sama dengan keputusan konsumen membeli Bibit kelapa sawit di PT. Bio Nusantara Teknologi Bengkulu, maka akan digunakan koefisien korelasi berganda, dengan rumus :

$$
\mathrm{R}=\sqrt{\frac{b_{1} \sum X_{1} Y+b_{2} \sum X_{2} Y+b_{3} \sum X_{3} Y}{\sum Y^{2}}}
$$

Koefisien korelasi diinterpretasikan berikut ini:

$\begin{array}{ll}\text { Intervasi Koefisien } & \text { Tingkat Hubungan } \\ \text { Korelasi } & \\ 0,000-0,199 & \text { Sangat Lemah } \\ 0,200-0,399 & \text { Lemah } \\ 0,400-0,599 & \text { Cukup/Sedang } \\ 0,600-0,799 & \text { Kuat } \\ 0,800-1,000 & \text { Sangat Kuat }\end{array}$

\section{Koefisien Determinasi Berganda}

Analisis koefisien korelasi berganda digunakan untuk mengetahui presentase variasi naikturunnya keputusan konsumen (petani) membeli Bibit kelapa sawit di PT. Bio Nusantara Teknologi Bengkulu yang ditentukan oleh harga dan kualitas produk secara stimulan, dilakukan dengan melihat koefisien determinasi berganda $\left(\mathrm{R}^{2}\right)$, dengan rumus sebagai berikut:

$$
\mathrm{R}^{2}=\frac{b_{1} \sum X_{1} Y+b_{2} \sum X_{2} Y+b_{3} \sum X_{3} Y}{\sum Y^{2}}
$$

\section{Pengujian Hipotesis}

1. Uji F

Output hasil uji F dilihat untuk mengetahui pengaruh variabel independen terhadap variabel dependen secara keseluruhan (Ghozali, 2005). Kriteria pengujiannya adalah:

- Jika Probabilities value > derajat kesalahan/alpha 0,05 (5\%) maka Ho diterima atau Ha ditolak. Artinya variabel independen secara bersama-sama tidak mempengaruhi variabel dependen secara signifikan.

- Jika probabilities value < derajat kesalahan/alpha 0,05 (5\%) maka Ho ditolak dan Ha diterima; yang berarti bahwa variabel independen secara bersama-sama mempengaruhi variabel dependen secara signifikan.

2. Uji t

Output hasil uji t dilihat untuk mengetahui pengaruh variabel independen secara individu terhadap variabel dependen, dengan menganggap variabel bebas lainnya konstan (Ghozali, 2005) atau untuk menentukan hipotesis diterima atau ditolak. Rumus yang digunakan untuk uji t adalah:

$$
\mathrm{t}=\frac{b_{i}}{S b_{i}}
$$

Penetapan untuk mengetahui hipotesis diterima atau ditolak yaitu dengan membandingkan nilai thitung dengan nilai t-tabel, dengan ketentuan:

- Jika nilai t-hitung < t-tabel alpha 0,05 (5\%) maka Ho diterima atau Ha ditolak. Artinya variabel independen secara parsial (sendiri-sendiri) tidak berpengaruh terhadap variabel dependen.

Jika nilai t-hitung > t-tabel alpha 0,05 (5\%) maka Ho ditolak atau Ha diterima. Artinya variabel independen secara parsial (sendiri-sendiri) berpengaruh terhadap variabel dependen.

\section{HASIL DAN PEMBAHASAN}

\section{Deskripsi Penyebaran Kuesioner}

Sesuai dengan rencana penelitian, kuesioner yang disebarkan adalah sebanyak 50 eksemplar. Penyebaran kuesioner dilakukan selama 1 bulan penelitian dengan cara mendatangani lokasi pembibitan PT. Bio Nusantara Teknologi Bengkulu. Selain itu, peneliti juga menggunakan data-data nama dan alamat 
yang sudah ada pada pembibitan PT. Bio Nusantara Teknologi. Hal ini dilakukan untuk mempermudah mendapatkan responden penelitian.

Dari 50 kuesioner yang direncanakan, seluruh kuesioner telah didapatkan dan diisi dengan baik oleh responden. Tidak ada kuesioner yang tidak diisi dengan lengkap, sehingga respons rate penyebaran kuesioner adalah sangat baik (100\%). Respons rate yang sangat baik tersebut memberi gambaran bahwa jawaban responden lebih representatif dan sesuai kondisi yang ada di lapangan.

\section{Karakteristik Responden}

Responden dalam penelitian ini adalah konsumen yang membeli Bibit kelapa sawit pada PT. Bio Nusantara Teknologi Bengkulu yang diambil dengan teknik accidental sampling. Responden penelitian berjumlah 50 orang. Berdasarkan form karakteristik responden yang ada di dalam kuesioner, diperoleh karakteristik responden sebagaimana terangkum pada Tabel 4.1.

Berdasarkan hasil penyebaran kuesioner diperoleh rentang usia responden. Mayoritas konsumen yang membeli bibit kelapa sawit pada PT. Bio Nusantara Teknologi Bengkulu didominasi oleh kelompok usia 25-30 tahun. Kondisi ini menggambarkan bahwa rentang usia tersebut merupakan golongan usia muda dan matang.

Selanjutnya, proporsi perbandingan jenis kelamin dari total 50 orang responden tersebut, terdiri dari 45 orang laki-laki dan 5 orang perempuan. Perbandingan ini menunjukkan bahwa jumlah mayoritas konsumen yang membeli bibit kelapa sawit pada PT. Bio Nusantara Teknologi Bengkulu sekaligus yang bersedia mengisi dan mengembalikan kuesioner lebih didominasi oleh konsumen laki-laki.

Tingkat pendidikan responden terbanyak adalah SMA sebanyak 23 orang (26\%), diikuti oleh responden dengan pendidikan SMP dan sarjana. Sementara responden dengan pendidikan SD relatif sedikit. Hasil ini memberi gambaran bahwa dari tingkat pendidikan, responden sudah memiliki pendidikan yang cukup, sehingga mendukung usaha perkebunan yang dimiliki dan dikelolanya.

Luas lahan usaha yang dimiliki responden (petani pekebun) terluas adalah 2-3 hektar dengan jumlah responden sebanyak 20 orang, diikuti oleh respoden pekebun yang memiliki lahan seluar kurang dari 2 hektar (10 orang) dan lebih dari 10 hektar (8 orang).

Pengalaman bertani kebun responden terbanyak adalah antara 5 - 10 tahun (25 orang/50\%), diikuti oleh petani kebun dengan pengalaman kurang dari 5 tahun (20 orang) dan lebih dari 10 tahun sebanyak 5 orang. Hal ini menggambarkan bahwa responden petani pekebun telah memiliki pengalaman yang memadai dalam pengelolaan dan pengusahaan perkebunan kelapa sawit.

\section{Deskripsi Data Penelitian}

Variabel yang diteliti pada penelitian ini adalah harga, kualitas bibit dan keputusan pembelian konsumen. Berdasarkan hasil penelitian, dapat dideskripsikan ketiga variabel tersebut sebagaimana pemaparan berikut ini.

\section{Jawaban Responden terhadap Variabel Harga}

Variabel harga diukur dengan 4 item pertanyaan. Berikut ini disajikan persepsi responden terhadap variabel harga.

Berdasarkan Tabel 4.2 di atas, diketahui nilai rata-rata jawaban responden terhadap variabel harga/tarif sebesar 3,36. Rata-rata jawaban tersebut berada pada kategori cukup setuju $(2,60-3,39)$. Kondisi tersebut menggambarkan bahwa dari segi harga, rata-rata responden dalam hal ini responden menilai bahwa harga bibit PT. Bio Nusantara Teknologi Bengkulu cukup terjangkau. Walaupun pada sebagian konsumen, bibit PT. Bio Nusantara Teknologi Bengkulu dinilai memiliki harga yang cukup mahal, dibandingkan dengan bibit sawit dari perusahaan lain yang sejenis, namun konsumen tetap membeli bibit dari PT. Bio Nusantara Teknologi.

\section{Jawaban Responden terhadap Variabel Kualitas Produk}

Variabel produk diukur dengan 4 parameter. Jawaban responden terhadap tiap-tiap parameter menggunakan skala likert. Berikut ini disajikan persepsi responden terhadap variabel produk.

Berdasarkan Tabel 4.3 di atas, diketahui nilai rata-rata jawaban responden terhadap variabel produk sebesar 3,63. Nilai rata-rata jawaban tersebut berada pada kategori setuju $(3,40-4,19)$. Kondisi tersebut menggambarkan bahwa responden telah memiliki pengetahuan yang baik terhadap bibit PT. Bio Nusantara Teknologi Bengkulu, sehingga responden tidak memiliki keraguan untuk membeli dan menggunakan bibit perusahaan. 


\section{Jawaban Responden terhadap Variabel Keputusan Pembelian}

Variabel keputusan konsumen diukur dengan 5 parameter. Jawaban responden terhadap tiap-tiap parameter variabel keputusan konsumen menggunakan skala likert. Berikut ini disajikan persepsi responden terhadap variabel keputusan konsumen.

Berdasarkan Tabel 4.4 di atas, diketahui nilai rata-rata jawaban responden terhadap variabel keputusan konsumen sebesar 3,52. Nilai rata-rata jawaban tersebut berada pada kategori setuju (3,40 4,19). Kondisi tersebut menggambarkan bahwa konsumen akan melakukan pembelian bibit PT. Bio Nusantara Teknologi Bengkulu untuk memenuhi kebutuhan usaha perkebunan kelapa sawit miliknya. Keputusan konsumen ini dilandasi oleh keyakinan konsumen terhadap bibit PT. Bio Nusantara Teknologi Bengkulu dianggap sesuai dengan kebutuhan dan keinginan konsumen.

\section{Pengujian Asumsi Klasik Uji Normalitas}

Persyaratan pertama untuk penelitian adalah normalitas data. Hal ini dilakukan untuk mengetahui apakah data penelitian memenuhi asumsi kenormalan data. Uji normalitas yang dilakukan dalam penelitian adalah dengan melakukan uji Kolmogorov-Smirnov. Data-data yang berdistribusi normal memiliki nilai probabilitas > 0,05 (Ghozali, 2013). Hasil pengujian normalitas data dapat dilihat pada Tabel 3. berikut ini.

Tabel 3. Hasil Uji Normalitas Data Penelitian

\begin{tabular}{|c|l|c|c|c|}
\hline No & \multicolumn{1}{|c|}{ Variabel } & $\begin{array}{c}\text { Nilai Kolmogorov- } \\
\text { Smirnov }\end{array}$ & $\boldsymbol{p}$-value & Keterangan \\
\hline 1 & Harga & 1,143 & 0,147 & Normal \\
\hline 2 & Kualitas Produk & 1,283 & 0,074 & Normal \\
\hline 3 & Keputusan Petani & 1,170 & 0,129 & Normal \\
\hline
\end{tabular}

Sumber: Data diolah, 2019

Berdasarkan Tabel 3. terlihat bahwa seluruh nilai probabilitas ( $p$-value) variabel pengawasan sebesar lebih besar dari alpha 0,05; dengan demikian disimpulkan bahwa seluruh variabel penelitian berdistribusi normal.

\section{Uji Multikolonieritas}

Alat statisatik yang sering digunakan untuk menguji gangguan multikolinearitas adalah dengan variance inflation factor (VIF) dan nilai tolerance. Nilai cut off yang digunakan untuk mengidentifikasi adanya multikolenieritas adalah jika nilai VIF $>10$ atau nilai tolerance $<0,1$. Hasil pengujian multikolenieritas dapat dilihat pada Tabel 4. berikut ini.

Tabel 4. Hasil Uji Multikolenieritas

\begin{tabular}{|l|c|c|c|}
\hline \hline \multicolumn{1}{|c|}{ Variabel } & Nilai & Tolerance & Keterangan \\
\hline Harga & 3,430 & 0,292 & \multirow{2}{*}{ Bebas Multikolenieritas } \\
\hline Kualitas Produk & 2,674 & 0,374 & \\
\hline \hline
\end{tabular}

Sumber: Data diolah, 2019

Pada Tabel 4. terlihat bahwa nilai VIF kedua variabel adalah sebesar lebih kecil 10 dan nilai Tolerance ketiga variabel lebih besar 0,1. Dengan demikian disimpulkan bahwa kedua variabel tersebut bebas dari gejala multikolenieritas.

\section{Uji Heteroskedastisitas}

Uji heteroskedasitas adalah pengujian asumsi residual dengan varians tidak konstan. Model regresi yang baik apabila varians dari residual satu pengamatan ke pengamatan lain tetap atau homokedasitas. Metode yang digunakan untuk mendeteksi heteroskedasitas adalah dengan uji glejser dengan probabilitas ( $p$-value) $>0,05$ (Ghozali, 2013). Hasil pengujian heterosekedastisitas adalah sebagai berikut.

Tabel 5. Hasil Pengujian Heteroskedastisitas Data Penelitian

\begin{tabular}{|l|c|c|c|}
\hline \multicolumn{1}{|c|}{ Variabel } & t-test & Sig & Keterangan \\
\hline Harga & $-1,193$ & 0,243 & Bebas Heteroskedastisitas \\
\hline Kualitas Produk & 0,744 & 0,463 & Bebas Heteroskedastisitas \\
\hline
\end{tabular}

Sumber: Data diolah, 2019 
Berdasarkan Tabel 5. di atas, diketahui bahwa nilai probabilitas ( $p$-value) variabel kompetensi, sistem pengendalian intern pemerintah dan komitmen organisasional lebih besar dari 0,05 ( $p$-value > 0,05). Berdasarkan hasil tersebut, dapat disimpulkan bahwa variabel harga dan kualitas peodyk yang digunakan dalam penelitian ini memiliki varian yang homogen (bebas heterosekedastisitas).

\section{Hasil Analisis Data}

Analisis yang digunakan dalam penelitian ini adalah analisis regresi linier berganda (Multiple Regression Linear). Analisis yang dilakukan terhadap kerterkaitan pengaruh harga dan kualitas produk terhadap keputusan konsumen membeli bibit kelapa sawit pada PT. Bio Nusantara Teknologi Bengkulu. Adapun hasil analisis regresi tersebut diuraikan berikut ini.

Tabel 6. Hasil Analisis Regresi

\begin{tabular}{|c|c|c|c|c|}
\hline \multirow{2}{*}{ No } & \multirow{2}{*}{ Variabel Independen } & \multirow{2}{*}{ Koefisien $\beta$} & \multicolumn{2}{|c|}{ Nilai t } \\
\hline & & & Hitung & Sig. \\
\hline 1. & Harga $\left(\mathrm{X}_{1}\right)$ & 0,337 & 3,358 & $0,002^{*}$ \\
\hline & Kualitas Produk $\left(\mathrm{X}_{2}\right)$ & 0,265 & 3,007 & $0,004 *$ \\
\hline 2. & Konstanta (Intercept) & 0,972 & & \\
\hline 3. & Korelasi Berganda (R) & 0,972 & & \\
\hline 4. & Koefisien Determinasi $\left(\mathrm{R}^{2}\right)$ & 0,703 & & \\
\hline 5. & Adjusted $\mathrm{R}^{2}$ & 0,684 & & \\
\hline 6. & F-hitung & 36,328 & & 0,000 \\
\hline 7. & F-tabel $(\alpha 1 \%)$ & 2,810 & & \\
\hline 8. & t-tabel ( $\alpha 5 \%)$ & 1,645 & & \\
\hline
\end{tabular}

*) Signifikan pada level 0,05 (5\%)

Sumber : Hasil Penelitian 2019, diolah

Berdasarkan hasil analisis yang dilakukan seperti yang ditunjukkan pada Tabel 6, diperoleh persamaan regresi sebagai berikut:

$$
Y=0,972+0,337 X_{1}+0,265 X_{2}
$$

Dari persamaan regresi tersebut, dapat diintepretasikan sebagai berikut:

1) Nilai konstanta sebesar 0,972 menunjukkan bahwa keputusan konsumen membeli bibit kelapa sawit pada PT. Bio Nusantara Teknologi Bengkulu akan konstan (tetap) sebesar 0,972 jika harga dan kualitas produk sama dengan nol (tidak ada).

2) Nilai koefisien regresi variabel harga $\left(\mathrm{X}_{1}\right)$ sebesar 0,337 . Hasil ini menunjukkan bahwa harga mempengaruhi keputusan konsumen membeli bibit kelapa sawit pada PT. Bio Nusantara Teknologi Bengkulu sebesar 0,337.

3) Nilai koefisien regresi variabel produk $\left(\mathrm{X}_{2}\right)$ sebesar 0,265 , berarti bahwa produk mempengaruhi keputusan konsumen membeli bibit kelapa sawit pada PT. Bio Nusantara Teknologi Bengkulu sebesar 0,265 .

Kemudian, dari hasil analisis juga diperoleh nilai koefisien korelasi berganda (R) sebesar 0,972; yang berarti bahwa hubungan antara harga dan kualitas produk dengan keputusan konsumen membeli bibit kelapa sawit pada PT. Bio Nusantara Teknologi Bengkulu berada pada interval 0,800 - 1,000 dan berada pada kategori sangat kuat.

$\begin{array}{ll}\begin{array}{l}\text { Intervasi Koefisien } \\ \text { Korelasi }\end{array} & \text { Tingkat Hubung } \\ 0,000-0,199 & \text { Sangat Lemah } \\ 0,200-0,399 & \text { Lemah } \\ 0,400-0,599 & \text { Cukup/Sedang } \\ 0,600-0,799 & \text { Kuat } \\ 0,800-1,000 & \text { Sangat Kuat }\end{array}$

Sedangkan nilai koefisien determinasi $\left(\mathrm{R}^{2}\right)$ yang juga diperoleh dari hasil analisis data sebesar 0,703; yang berarti bahwa sumbangan variabel harga dan kualitas produk terhadap peningkatan keputusan konsumen bibit kelapa sawit pada PT. Bio Nusantara Teknologi Bengkulu sebesar 70,3\%. Sedangkan sisanya sebesar 29,7\% dijelaskan oleh faktor lain di luar model. 


\section{Hasil Pengujian Hipotesis}

Pengujian hipotesis dilakukan untuk membuktikan dugaan sementara (hipotesis) yang dirumuskan sebelumnya. Pengujian hipotesis dilakukan secara simultan menggunakan uji F dan secara parsial menggunakan uji t. Hasil-hasil tersebut selanjutnya diuraikan berikut ini.

Uji t

Uji t dilakukan untuk menguji pengaruh variabel bebas secara parsial terhadap variabel terikat, dalam hal ini adalah pengaruh variabel harga dan kualitas produk terhadap keputusan konsumen membeli bibit kelapa sawit pada PT. BNT Bengkulu. Kriteria pengujiannya adalah sebagai berikut :

- Jika nilai t-hitung < t-tabel sebesar 1,645; maka disimpulkan bahwa harga dan kualitas produk secara parsial tidak berpengaruh terhadap keputusan konsumen membeli bibit kelapa sawit pada PT. BNT Bengkulu.

- Jika nilai t-hitung > t-tabel 1,645 maka disimpulkan bahwa harga dan kualitas produk secara parsial berpengaruh signifikan terhadap keputusan konsumen membeli bibit kelapa sawit pada PT. Bio Nusantara Teknologi Bengkulu.

Dari hasil perhitungan yang diperoleh nilai t-hitung variabel harga dan kualitas produk adalah sebagai berikut:

- $\quad$ Nilai t-hitung variabel harga sebesar 3,358 >t-tabel 1,645. Hasil ini berarti berarti harga berpengaruh signifikan terhadap keputusan konsumen membeli bibit kelapa sawit pada PT. Bio Nusantara Teknologi Bengkulu.

- $\quad$ Nilai t-hitung variabel produk sebesar 3,007 > t-tabel 1,645. Hasil ini berarti berarti produk berpengaruh signifikan terhadap keputusan konsumen membeli bibit kelapa sawit pada PT. Bio Uji F Nusantara Teknologi Bengkulu.

Uji F dilakukan untuk menguji pengaruh variabel bebas secara simultan terhadap variabel terikat, dalam hal ini adalah pengaruh variabel harga dan kualitas produk secara simultan terhadap keputusan konsumen membeli bibit kelapa sawit pada PT. Bio Nusantara Teknologi Bengkulu. Kriteria pengujiannya adalah sebagai berikut :

- Jika nilai F-hitung < F-tabel 2,810; maka disimpulkan bahwa variabel harga dan kualitas produk secara simultan (bersama-sama) tidak berpengaruh terhadap keputusan konsumen membeli bibit kelapa sawit pada PT. Bio Nusantara Teknologi Bengkulu.

- Jika nilai F-hitung > F-tabel 2,810; maka disimpulkan bahwa variabel harga dan kualitas produk secara simultan (bersama-sama) berpengaruh signifikan terhadap keputusan konsumen membeli bibit kelapa sawit pada PT. Bio Nusantara Teknologi Bengkulu.

Dari hasil penelitian diperoleh nilai F-hitung sebesar 36,328 > F-tabel 2,810; maka dapat disimpulkan bahwa secara simultan variabel harga dan kualitas produk berpengaruh signifikan terhadap keputusan konsumen membeli bibit kelapa sawit pada PT. Bio Nusantara Teknologi Bengkulu.

\section{Pembahasan}

Berdasarkan hasil analisis diketahui bahwa secara simultan (bersama-sama) variabel bebas (harga dan kualitas produk) berpengaruh signifikan terhadap keputusan konsumen. Pemaparan hasil penelitian secara parsial mengenai pengaruh masing-masing variabel bebas secara lengkap dijelaskan berikut ini.

\section{Pengaruh Harga terhadap Keputusan Pembelian}

Berdasarkan hasil penelitian diketahui bahwa harga berpengaruh signifikan terhadap keputusan konsumen membeli bibit kelapa sawit pada PT. Bio Nusantara Teknologi Bengkulu. Hal ini terlihat dari besarnya nilai t-hitung variabel harga sebesar 3,358 >t-tabel 1,645. Hasil ini mengindikasikan bahwa harga berpengaruh terhadap keputusan konsumen.

Dari hasil penelitian, disimpulkan bahwa harga merupakan salah satu faktor yang penting mempengaruhi pertimbangan konsumen dalam membeli suatu produk. Harga yang dipersepsikan terjangkau dan memiliki kesesuaian dengan kualitas produk akan mempengaruhi keputusan konsumen.

Dalam suatu produk terkandung nilai ekonomis yang pada umumnya disebut harga. Menurut Tjiptono (2005: 157) Harga hanyalah merupakan salah satu dari bauran pemasaran oleh karena itu Harga perlu dikondisikan dan saling mendukung dengan bauran pemasaran lainnya yaitu produk, distribusi, dan promosi.

Jadi harga adalah sejumlah uang yang harus dibayarkan konsumen guna memperoleh produk berupa barang dan atau jasa yang dimaksud kepada pihak yang menawarkannya. Harga dalam bentuk nominal uang yang harus dibayarkan telah melalui proses kesepakatan antara kedua belah pihak. Benturan 
antara kedua kepentingan dan pengaruh harga terhadap kedua belah pihak merupakan proses yang tidak mudah. Kedua hal tersebut tidak bisa dipisahkan karena sama penting dan berpengaruh.

\section{Pengaruh Kualitas Produk terhadap Keputusan Pembelian}

Berdasarkan hasil analisis statistik diketahui bahwa kualitas produk berpengaruh signifikan terhadap keputusan konsumen membeli bibit kelapa sawit pada PT. Bio Nusantara Teknologi Bengkulu. Hal ini terlihat dari besarnya nilai t-hitung variabel produk sebesar 3,007 >t-tabel 1,645. Hasill ini berarti bahwa jika kualitas produk yang semakin tinggi akan meningkatkan keputusan konsumen membeli produk tersebut.

Produk adalah sesuatu yang dijual oleh penjual. Oleh karena itu, produk harus memiliki kualitas yang tinggi, sehingga dapat meningkatkan keinginan konsumen untuk membeli produk. Hal ini sebagaimana pendapat Kotler dan Armstrong (2006:33) mengenai kualitas produk sebagai segala sesuatu yang dapat ditawarkan kepada pasar untuk diperhatikan, dibeli, digunakan atau dikonsumsikan yang memiliki kemampuan dalam memenuhi kebutuhan konsumen. Istilah produk mencakup, benda fisik, jasa, kepribadian, tempat ide, serta organisasi. Pengertian sebagaimana definisi tersebut termasuk jasa. Sedangkan pengertian jasa itu sendiri adalah barang yang tidak kentara (intangible goods) yang di beli dan di jual di pasar melalui suatu transaksi pertukaran yang saling memuaskan.

Kualitas produk yang ditawarkan haruslah memenuhi harapan konsumen. Oleh karena itu, melalui usaha promosi yang dilakukan oleh produsen dan penjual dapat menginformasikan kualitas produk yang ditawarkan sehingga memberikan informasi mengenai kualitas produk tersebut kepada konsumen. Informasi-informasi mengenai kualitas produk tersebut selanjutnya akan dipertimbangkan sebagai salah satu faktor penentu keputusan konsumen membeli produk. Jika produk tersebut memang benar-benar berkualitas dan dibutuhkan oleh konsumen, maka konsumen dengan pertimbangan informasi yang diperoleh dari promosi produsen dan penjual, akan memutuskan untuk membeli.

\section{Pengaruh Harga dan Kualitas Produk terhadap Keputusan Pembelian}

Berdasarkan hasil analisis statistik diketahui bahwa secara bersama-sama harga dan kualitas produk berpengaruh signifikan terhadap keputusan konsumen membeli bibit kelapa sawit pada PT. Bio Nusantara Teknologi Bengkulu. Hal ini terlihat dari besarnya nilai F-hitung variabel harga dan kualitas produk sebesar 36,328 > F-tabel 2,810. Hasill ini berarti bahwa jika harga dipersepsikan terjangkau dan kualitas produk yang semakin tinggi akan meningkatkan keputusan konsumen membeli produk tersebut.

Faktor harga dapat mempengaruhi keputusan konsumen dalam membeli produk. Harga adalah sejumlah uang yang harus dibayarkan konsumen guna memperoleh produk berupa barang dan atau jasa yang dimaksud kepada pihak yang menawarkannya. Harga dalam bentuk nominal uang yang harus dibayarkan telah melalui proses kesepakatan antara kedua belah pihak.

Selain harga, faktor kualitas produk juga dapat mempengaruhi keputusan konsumen. Kualitas produk merupakan jaminan atas kemampuan produk dalam melaksanakan fungsinya saat digunakan atau dipakai oleh konsumen setelah membeli produk.

Keterkaitan antara harga dan kualitas produk, tentu saja ada keterkaitan yang erat, di mana produk berkualitas tentu saja akan memiliki tingkat harga yang relatif lebih tinggi dibandingkan dengan produkproduk dengan kualitas rendah. Oleh karena itu, produsen atau penjual dapat menjual produk-produk dengan kualitas tinggi kepada konsumen, sehingga konsumen tidak merasa kecewa dengan keputusan pembelian yang dilakukannya. Seperti halnya yang dilakukan oleh PT. Bio Nusantara Teknologi dalam menjual bibit kelapa sawit (produk) yang memiliki sertifikat resmi, sehingga memberikan jaminan kualitas kepada petani yang membeli bibit, dan dijual kepada konsumen lebih tinggi dibandingkan harga bibit tanpa sertifikat dari para pesaing.

\section{KESIMPULAN}

1. Harga berpengaruh positif dan signifikan terhadap keputusan petani membeli bibit kelapa sawit di PT. Bio Nusantara Teknologi Bengkulu. Hasil ini bermakna bahwa jika bibit dipersepsikan terjangkau, maka keputusan petani membeli bibit akan semakin tinggi.

2. Kualitas bibit berpengaruh positif dan signifikan terhadap keputusan petani membeli bibit kelapa sawit di PT. Bio Nusantara Teknologi Bengkulu. Hasil ini bermakna bahwa jika kualitas bibit dipersepsikan semakin tinggi, maka keputusan petani membeli bibit akan semakin tinggi.

3. Harga dan kualitas bibit berpengaruh positif dan signifikan terhadap keputusan petani membeli bibit kelapa sawit di PT. Bio Nusantara Teknologi Bengkulu. Hasil ini bermakna bahwa jika bibit dipersepsikan terjangkau dan kualitas bibit semakin baik, maka keputusan petani membeli bibit akan semakin tinggi. 


\section{DAFTAR PUSTAKA}

Bio Nusantara Teknologi, PT. 2018. Profil Perusahaan, PT. BNT Bengkulu

BPS, 2018. Bengkulu Utara Dalam Angka, Badan Pusat Statistik Kabupaten Bengkulu Utara

Dinas Pertanian Provinsi Bengkulu, 2018. Laporan Tahunan Pertanian, Dispertan Provinsi Bengkulu

Ghozali, Iman, 2005. Analisis Multivariate dengan Program SPSS, Andi Offset, Yogyakarta

Kotler, P. \& G. Armstrong, 2006. Manajemen Pemasaran Global, PT. Indeks, Jakarta

Kotler, Philip, 2010. Manajemen Pemsaran Internasional, Prenhalindo, Jakarta

Rangkuti, Fredy, 2003. Marketing Analysis Made Easy: Teknis Analisis Pemasaran dan Analisis Kasus Menggunakan Excel dan SPSS, Gramedia Pustaka Utama, Jakarta.

Sugiyono, 2010. Metode Penelitian Bisnis, Alfabeta, Bandung

Sukirno, Sadono, 2012. Pengantar Ekonomi Makro, BPFE, Yogyakarta

Tjiptono, Fandy, 2007. Pengantar Manajemen Pemasaran, Gramedia Pustaka Utama, Jakarta. 